\title{
Beata Dubiel
}

Uniwersytet Ekonomiczny w Katowicach

e-mail: beata.dubiel@ue.katowice.pl

\section{WYKORZYSTANIE INSTRUMENTÓW \\ W ZARZĄDZANIU RYZYKIEM ŚRODOWISKOWYM W GMINACH ŚLĄSKICH}

\section{THE USE OF INSTRUMENTS \\ IN ENVIRONMENTAL RISK MANAGEMENT \\ IN THE SILESIAN MUNICIPALITIES}

DOI: $10.15611 /$ pn.2018.532.07

JEL Classification: Q56, R58

Streszczenie: Zarządzanie ryzykiem środowiskowym w samorządach lokalnych realizuje się za pomocą odpowiednich instrumentów, które obejmują rozwiązania prawne, ekonomiczne i techniczne oraz wpływają na stopień wykorzystania użytych zasobów. Celem artykułu jest zaprezentowanie oraz omówienie instrumentów wykorzystywanych przez gminy w procesie zarządzania ryzykiem środowiskowym. Omówione zostaną wyniki badań empirycznych przeprowadzonych w okresie 2016-2017 wśród samorządów szczebla gminnego w województwie śląskim. Wyniki potwierdziły, iż gminy śląskie są bardzo dobrze przygotowane w zakresie dokumentacji, planów zarządzania kryzysowego co zapewnia właściwe reagowanie na zdarzenia katastroficzne. Dokumenty pozwalają samorządom zrealizować konkretne cele służące przede wszystkim bezpieczeństwu lokalnemu.

Słowa kluczowe: ryzyko środowiskowe, instrumenty zarządzania ryzykiem środowiskowym, samorząd lokalny, ryzyko powodziowe, dokumentacja planowania.

Summary: Environmental risk management in local self-governments is carried out by means of appropriate instruments that include legal, economic and technical solutions and they have influence on the degree of use of the exploited resources. The purpose of the article is to present and to discuss the instruments used by municipalities in the process of environmental risk management. There will be presented the results of empirical research carried out in the period 2016-2017 among local government authorities in the province Silesia. The results confirmed that the Silesian municipalities are very well prepared as far as documentation and crisis management plans are concerned, which ensures proper response to catastrophic events. The documents allow local governments to achieve specific goals serving primarily local security.

Keywords: ecological risk, environmental risk management instruments, local government, flood risk, planning documents. 


\section{Wstęp}

Ryzyko jest nieodłącznym elementem wszelkiej działalności człowieka, w tym również działalności społecznej i gospodarczej, stanowi jeden z podstawowych obiektów zainteresowań człowieka mającego na celu optymalizację tej działalności. Ciągłe dążenie do maksymalizacji zysku wymusiło potrzebę zajęcia się tzw. technologią ryzyk, a więc profesjonalnym, planowym i zorganizowanym diagnozowaniem i przeciwdziałaniem stratom powstającym w wyniku realizacji różnych ryzyk określanym jako proces zarządzania ryzykiem. Zarządzanie ryzykiem jest procesem opanowywania ryzyka obejmującym ogół działań związanych z analizą, eliminowaniem, ograniczaniem oraz zarządzaniem ryzykiem $\mathrm{w}$ konkretnym przypadku [Monkiewicz 2000].

Ryzyko środowiskowe, zgodnie z definicją Environmental Protection Agency, oznacza prawdopodobieństwo, że dane zdarzenie lub działanie spowoduje szkody dla zdrowia lub/i środowiska [EPA 1992]. Ryzyko środowiskowe może być powodowane przez dwa rodzaje oddziaływań, a mianowicie:

- oddziaływanie sił przyrody na człowieka i gospodarkę,

- oddziaływanie człowieka, prowadzonej przez niego działalności na środowisko.

Zarządzanie ryzykiem środowiskowym mającym swe źródła w działaniu sił natury jest procesem, w którym można wyróżnić rozwiązania tradycyjne oraz innowacyjne. W ujęciu tradycyjnym proces zarządzania takim ryzykiem składa się z trzech głównych etapów: przygotowania, reagowania i odbudowy. Zadania realizują głównie samorządy terytorialne. Zarządzanie ryzykiem środowiskowym w samorządach lokalnych realizuje się za pomocą odpowiednich instrumentów, które obejmują rozwiązania prawne, ekonomiczne i techniczne oraz wpływają na stopień wykorzystania użytych zasobów. W literaturze przedmiotu instrumenty polityki ekologicznej najczęściej dzieli się w zależności od sposobu działania na instrumenty regulacji bezpośredniej, którymi są instrumenty o charakterze administracyjno-prawnym, i instrumenty regulacji pośredniej, obejmujące instrumenty ekonomiczne. Instrumenty są narzędziami służącymi oddziaływaniu państwa na podmioty gospodarcze.

W przedmiotowym artykule zostaną zaprezentowane dane, które pozwoliły na zidentyfikowanie podejmowanych działań przez gminy w zakresie poprawy bezpieczeństwa, zwłaszcza przeciwpowodziowego na etapie planowania i działalności prewencyjnej. Omówione zostaną także instrumenty wykorzystywane przez gminy w procesie zarządzania ryzkiem środowiskowym. Celem głębszego zbadania tego zagadnienia było podjęcie badań empirycznych w gminach województwa śląskiego. Badania przeprowadzone w okresie 2016-2017, z wykorzystaniem dwóch głównych narzędzi, tj. kwestionariusza ankiety skierowanego do władz samorządowych szczebla gminnego oraz wywiadu bezpośredniego prowadzonego osobiście z respondentami, umożliwiły ocenę występujących zagrożeń spowodowanych siłami natury, zagrożeń chemicznych oraz innych ryzyk i zagrożeń a także na wskazanie częstotliwości ich występowania. Kwestionariusz skierowany do jednostek samorządu lokal- 
nego zawierał 23 pytania, które były w formie zamkniętej, półotwartej oraz pytania, gdzie podporządkowywana była siła oddziaływania badanego zjawiska w sposób liczbowy. W rezultacie badań empirycznych materiał badawczy, który został wykorzystany do opracowania prezentowanych wyników, oparty został na 110 ankietach (zwrotność badania na poziomie 60\%) pozyskanych od:

- 16 miast na prawach powiatu (zwrotność $85 \%$ ),

- 24 gmin miejskich (zwrotność 50\%),

- 14 gmin miejsko-wiejskich (zwrotność 59\%),

- 56 gmin wiejskich (zwrotność 59\%).

Zebrany materiał źródłowy pozwolił na rozpoznanie czy lokalne samorządy posiadają wypracowane podstawowe dokumenty planistyczne oraz strategiczne mające na celu zapewnienie bezpieczeństwa mieszkańcom, w szczególności: ekologicznego, przeciwpowodziowego, socjalnego.

\section{Wybrane instrumenty zarządzania ryzykiem środowiskowym}

Dobór odpowiednich instrumentów do realizacji stawianych celów publicznych stanowi dużą umiejętność zarządzających. Bardzo rzadko występuje sytuacja, gdy zakładany efekt $\mathrm{w}$ gospodarce samorządowej zależy od zastosowania jednego instrumentu. Tak jak np. w stymulowaniu przedsiębiorczości lokalnej niezbędne jest uwzględnienie kilku rozwiązań, wzajemnie ze sobą skojarzonych. Oznacza to, że powodzenie pożądanych zmian wymaga użycia zestawu celnie dobranych narzędzi nakierowanych na poszczególne elementy przedmiotu oddziaływania. W ten sposób zapewniona zostaje kompletność ujęcia w zarządzaniu i w prowadzeniu polityki lokalnej. Harmonizowanie działalności różnych podmiotów odbywa się właśnie za pomocą różnych instrumentów [Zalewski 1994].

W literaturze przedmiotu wyróżnia się różne klasyfikacje instrumentów realizujących cele w procesie zarządzania ryzykiem środowiskowym, katastroficznym a zwłaszcza ryzykiem powodzi. Do celów niniejszych rozważań posłużono się prostym podziałem narzędzi, biorąc pod uwagę ich przydatność praktyczną, zaprezentowano zatem przykładowe, wybrane narzędzia. Niektóre instrumenty mogą spełniać różnorodne funkcje i przynależeć jednocześnie do dwóch grup instrumentów.

Do instrumentów administracyjno-prawnych, którymi posługują się samorządy terytorialne $\mathrm{w}$ procesie zarządzania ryzykiem środowiskowym należy zakwalifikować m.in. instrumenty związane z zarządzaniem wodami. Mowa tu o pozwoleniach wodnoprawnych, w których ustala się cel i zakres korzystania $\mathrm{z}$ wód, warunki wykonywania uprawnienia oraz obowiązki konieczne do przestrzegania ze względu na ochronę zasobów środowiska, interesów ludności i gospodarki. Pozwolenia wodnoprawne są wymagane na działania związane m.in. z: poborem wód powierzchniowych i podziemnych, odprowadzaniem ścieków do wód i powierzchni ziemi, wykonywaniem urządzeń wodnych, długotrwałym obniżeniem zwierciadła wody podziemnej, odwodnieniem obiektów lub wykopów budowlanych. Na mocy Prawo 
wodne pozwolenie wodnoprawne zostało objęte kategorią tzw. zgody wodnoprawnej [Ustawa z 20 lipca 2017]. Organem właściwym w sprawach o wydanie pozwoleń jest dyrektor Regionalnego Zarządu Gospodarki Wodnej Wód Polskich. W przypadku gdy o pozwolenie występują Wody Polskie, właściwym do jego wydania jest minister środowiska.

Instrumentami służącymi bezpośrednio realizacji polityki ochrony środowiska, a także zarządzania ryzykiem środowiskowym są programy ochrony środowiska. Uchwalane są co cztery lata na odpowiednich szczeblach samorządu terytorialnego, tj. wojewódzkim, powiatowym oraz gminnym. Za ich przygotowanie, a następnie wykonanie postanowień odpowiedzialna jest administracja samorządowa. Instytucja programów ochrony środowiska została pomyślana jako instrument mający w większym stopniu pozwolić na efektywne zarządzanie ochroną środowiska i zapewnić koordynację działań podejmowanych w tym zakresie na poszczególnych szczeblach administracji samorządowej. Celem programów jest realizacja polityki ekologicznej państwa i z tego też względu muszą one spełniać te same wymagania oraz zawierać takie same elementy.

Instrumenty o charakterze planistycznym związane są z planowaniem przestrzennym, które jest prowadzone na trzech poziomach tj. lokalnym, regionalnym oraz krajowym. W ustawie o planowaniu i zagospodarowaniu przestrzennym najbardziej szczegółowo uregulowane jest planowanie przestrzenne na najniższym poziomie czyli w samorządach lokalnych. W planowaniu i zagospodarowaniu przestrzennym uwzględnia się m.in. wymagania ochrony środowiska, w tym gospodarowania wodami, wymagania dotyczące ochrony przeciwpowodziowej. W studium uwarunkowań i kierunków zagospodarowania przestrzennego gminy należy mieć na względzie, między innymi uwarunkowania dotyczące ochrony przeciwpowodziowej, określa się obszary szczególnego zagrożenia powodzią oraz obszary osuwania się mas ziemnych.

$\mathrm{W}$ miejscowych planach zagospodarowania przestrzennego realizowane są zadania własne gminy mające na celu zaspokajanie zbiorowych potrzeb wspólnoty. Są to m.in. zadania $\mathrm{z}$ zakresu infrastruktury technicznej, obejmujące kwestie wodociągów i zaopatrzenia w wodę, kanalizacji, usuwania i oczyszczania ścieków komunalnych, utrzymania czystości i porządku oraz urządzeń sanitarnych, składowisk i unieszkodliwiania odpadów komunalnych. Właściwie realizowane zadania pozwalają na minimalizację realizacji ryzyka ekologicznego na terytorium danej gminy.

Do instrumentów zarządzania zasobami wodnymi zalicza się m.in. planowanie w gospodarowaniu wodami, które obejmuje uwzględnienie planów operacyjnych ochrony przed powodzią oraz planów przeciwdziałania skutkom suszy na obszarze państwa. Przedmiotowe plany powinny obejmować powiększenie dyspozycyjnych zasobów wodnych oraz rezerw pojemności powodziowej, kształtowanie dolin rzecznych oraz wykorzystanie naturalnej retencji, budowę oraz rozbudowę lub przebudowę urządzeń wodnych. Plany te powinny wpisywać się w strategie rozwoju województw oraz plany zagospodarowania przestrzennego województw. W planach 
ochrony przeciwpowodziowej należy uwzględnić obszary narażone na niebezpieczeństwo powodzi wskazane we wstępnej ocenie ryzyka powodziowego. Dla tych obszarów sporządza się mapy zagrożenia powodziowego oraz mapy ryzyka powodziowego.

Ochrona przed powodzią jest zadaniem organów administracji rządowej i samorządowej. Użytkownicy wód współpracują z organami administracji rządowej i samorządowej w ochronie przed powodzią, w zakresie określonym w przepisach ustawy Prawo wodne oraz w odrębnych przepisach. Ochronę przed powodzią prowadzi się z uwzględnieniem map zagrożenia powodziowego, map ryzyka powodziowego oraz planów zarządzania ryzykiem powodziowym. Wskazane ramy dla oceny ryzyka powodziowego oraz zarządzania nim wprowadziła Dyrektywa 2007/60/WE, zwana potocznie Dyrektywą Powodziową.

Mapy zagrożenia powodziowego oraz ryzyka powodziowego, jak wspomniano, muszą zostać uwzględnione w dokumentach planistycznych gmin. Mapy są dostępne dla samorządów lokalnych i wskazują obszary, na których będą obowiązywać pewne ograniczenia użytkowania terenów dla właścicieli. Na terenach zagrożonych powodziami właściciele nie będą mogli rozpocząć budowy nowej nieruchomości, posiadłości zlokalizowane na terenach zalewowych stracą na wartości rynkowej, ograniczona zostanie zabudowa $\mathrm{w}$ miejscach, gdzie nawet raz na sto lat występują powodzie. Takie tereny zostaną bowiem uznane za obszary szczególnego zagrożenia powodziowego. Wspomniane ograniczenia mogą spowodować narażenie gmin na pojawienie się roszczeń odszkodowawczych od właścicieli takich terenów, na których wystąpią ograniczenia inwestycyjne.

Na poziomie lokalnym zaspokajanie zbiorowych potrzeb wspólnoty należy do zadań własnych gminy. Wójt (burmistrz, prezydent miasta), jako organ wykonawczy gminy, odpowiada za opracowanie planu operacyjnego ochrony przed powodzią, ogłaszanie i odwoływanie pogotowia i alarmu przeciwpowodziowego, a ponadto jeśli w inny sposób nie można usunąć bezpośredniego niebezpieczeństwa dla życia ludzi lub dla mienia - może zarządzić ewakuację z obszarów bezpośrednio zagrożonych. Plan operacyjny ochrony przed powodzią może być jednym ze składników planu zarządzania kryzysowego lub też odrębnym dokumentem operacyjnym w samorządzie.

Jednostki samorządu terytorialnego szczebla powiatowego lub gminnego w ramach realizacji zadań z zakresu ochrony przed powodzią mogą opracować i uchwalić lokalny plan ograniczania skutków powodzi i profilaktyki powodziowej. Przedmiotem planu lokalnego jest identyfikacja zagrożenia powodziowego na danym obszarze, określenie wszelkich możliwych działań, które mogą ograniczyć skutki powodzi oraz przedstawienie sposobów i środków przeciwdziałania ryzyku powodzi.

Kompleksowy program zapobiegania powodzi powinien obejmować zarówno działania w gospodarce leśnej, rolnictwie (odpowiednia zmiana zabiegów agrotechnicznych czy sposobu użytkowania gruntów na terenach nadrzecznych), planowaniu przestrzennym i gospodarce wodnej, jak i tworzenie odpowiednich rozwiązań legi- 
slacyjnych. Niezmiernie ważne dla ograniczenia strat w przypadku wystąpienia powodzi ma też odpowiedni system prognoz i wczesnego rozpoznania zagrożenia a nawet edukacja lokalnych społeczności żyjących na terenach zagrożonych powodzią.

\section{Narzędzia zarządzania ryzykiem w gminach śląskich}

Badane samorządy lokalne województwa śląskiego zostały poproszone o wskazanie ryzyk mających swe źródło w działaniu sił natury, które występują na terenie gminy. Wyniki wskazały na występujące ryzyka w szczególności: powodzie, podtopienia, silne huraganowe wiatry, trąby powietrzne, susze, nadmierne opady śniegu i oblodzenia, wstrząsy sejsmiczne oraz gradobicia. W kwestionariuszu przyjęto umowną częstotliwość realizacji omawianych ryzyk celem ujednolicenia udzielanych odpowiedzi.

Na potrzeby prowadzonych badań w gminach województwa śląskiego analizie zostały poddane wybrane dokumenty, plany oraz programy, które regulują lub umożliwiają zapewnienie bezpieczeństwa lokalnym społecznościom, w szczególności bezpieczeństwa ekologicznego, powodziowego, publicznego czy socjalnego.

Obowiązek tworzenia i aktualizacji planów zarządzania kryzysowego na poziomie gmin nakłada ustawa o zarządzaniu kryzysowym. Badane gminy doskonale wywiązały się z zobowiązań prawnych, wyniki wskazują, iż ponad 90\% samorządów sporządziło plany zarządzania kryzysowego. Pozostałych $8 \%$ gmin obecnie pracuje nad przygotowaniem dokumentów. Plany podlegają systematycznej aktualizacji podobnie jak analiza zagrożeń, która musi być opracowana indywidualnie dla każdej jednostki samorządu terytorialnego. Weryfikacja oraz stałe doskonalenie dokumentacji powinny wynikać nie tylko ze zmian legislacyjnych ale przede wszystkim z doświadczeń praktycznych pozyskiwanych przez odpowiednie służby publiczne.

Gminne plany zarządzania kryzysowego stanowią jedno z podstawowych narzędzi włodarza oraz gminnego zespołu zarządzania kryzysowego w przypadku wystąpienia zagrożenia powodującego lub mogącego spowodować sytuację kryzysową o skali wymagającej koordynacji prowadzonych działań ratowniczo-zapobiegawczych. Dokumenty pozwalają samorządom zrealizować konkretne cele służące przede wszystkim bezpieczeństwu lokalnemu. Wśród nadrzędnych celów zawartych w planach respondenci wskazywali na:

- systemowe, skoordynowane i efektywne reagowanie administracji publicznej gminy na zdarzenia kryzysowe ( $87 \%$ wskazań),

- właściwe prowadzenie działań w zakresie kierowania i nadzoru podczas reagowania kryzysowego (86\% wskazań),

- informowanie, ostrzeganie i alarmowanie ludności, współdziałanie oraz łączność podczas akcji ratownictwa, ewakuacji ( $42 \%$ wskazań),

- udzielanie pomocy społecznej oraz psychologicznej ewakuowanym lub poszkodowanym w wyniku zdarzenia kryzysowego (16\% wskazań), 
- udzielanie pomocy medycznej, organizacja ratownictwa (12\% wskazań),

- zapewnienie porządku publicznego oraz szacowanie szkód (57\% wskazań).

$\mathrm{W}$ dalszej kolejności analizie poddano plany bezpieczeństwa ekologicznego, jako dokumenty pozwalające na stworzenie warunków bezpieczeństwa ekologicznego i ochrony przed nadzwyczajnymi zagrożeniami środowiska w gminach. Przebadane jednostki samorządu terytorialnego sporządzają tylko te dokumenty, które są ustawowo wymagane. Planu bezpieczeństwa ekologicznego niestety nie sporządziła żadna z badanych gmin, tylko 2 gminy uznały, że mają w planie opracowanie takiego dokumentu. Innym dokumentem obligatoryjnym dla gmin jest program ochrony środowiska, który przygotowało $96 \%$ ankietowanych jednostek. Pozostałe gminy pracują nad opracowaniami. Zdecydowana większość samorządów ( $84 \%$ wskazań) zleciła opracowanie programu jednostkom zewnętrznym, najczęściej ekspertom z zakresu ochrony środowiska. Gminy ( $16 \%$ wskazań), które skonstruowały samodzielnie dokumentacje, opierały się głównie na współpracy pomiędzy kompetentnymi wydziałami oraz jednostkami podległymi administracji samorządowej.

Samorządy lokalne szczebla gminnego uchwalały gminne programy ochrony środowiska w dosyć dużej rozpiętości czasowej, tj. od 2002 do 2011 r. Ostatecznie niemal $100 \%$ gmin posiada taki dokument. Omawiane programy, podobnie jak większość dokumentacji planistycznej czy organizacyjnej w samorządach, podlegają systematycznej aktualizacji, co potwierdzają także wyniki badań empirycznych. W zdecydowanej większości odpowiedzi respondenci wskazali na uaktualnianie i dopasowanie projektów do aktualnych problemów i potrzeb gminy.

Proces opracowania programów ochrony środowiska, w opiniach zdecydowanej większości gmin, bo aż 89\%, opiera się na generalnej zasadzie włączania lokalnej społeczności zarówno w przygotowanie programu jak i jego wdrażanie. Samorządy prowadziły tzw. procesy otwartego planowania, wykorzystując m.in. takie narzędzia, jak: konsultacje społeczne, spotkania robocze z przedstawicielami urzędów gmin/miast, jednostek podległych, konsultacje z przedstawicielami organizacji pozarządowych, podmiotów gospodarczych i innych.

Programy ochrony środowiska przedstawiają aktualną sytuację ekologiczną gmin, uwzględniając uwarunkowania zewnętrzne i wewnętrzne, w tym ekologiczne, przestrzenne, społeczne i ekonomiczne uwarunkowania rozwoju gmin. Programy określają priorytetowe działania ekologiczne oraz harmonogram wdrażanych zadań ekologicznych w samorządach. Dokumenty omawiają a także regulują najistotniejsze zagadnienia oraz problemy z zakresu ochrony środowiska.

Z przeprowadzonych rozważań wynika, iż samorządy gminne poprawnie wypełniają obowiązki nakładane przez ustawodawcę w zakresie opracowania gminnych programów ochrony środowiska. Dokumenty poruszają istotne kwestie w zakresie ochrony środowiska na szczeblu lokalnym oraz kształtują politykę władz w zakresie realizacji polityki ekologicznej państwa.

Kolejnymi dokumentami o charakterze planistycznym, do opracowania których został zobowiązany (Ustawą o planowaniu i zagospodarowaniu przestrzennym 
[Ustawa z 27 marca 2003]) samorząd gminny są: miejscowy plan zagospodarowania przestrzennego oraz studium uwarunkowań i kierunków zagospodarowania przestrzennego gminy. Zadaniem gminy jest inwestowanie w infrastrukturę techniczną oraz przygotowanie terenu pod inwestycje. Jednym z głównych zadań gminy powinno być tworzenie korzystnych warunków rozwoju lokalnej przedsiębiorczości.

Wszystkie elementy rozwoju przedsiębiorczości lokalnej w gminie władze samorządowe powinny ując w miejscowych planach zagospodarowania i strategiach rozwoju gospodarczego lub rozwoju przedsiębiorczości. Posiadanie tego typu dokumentów, uchwalonych przez rady gminne, ułatwi otrzymanie wsparcia finansowego zarówno dla gmin na rozwój infrastruktury komunalnej, drogowej, jak i na inwestycje dla miejscowych przedsiębiorców.

Przeprowadzona analiza wyposażenia badanych samorządów w dokumenty planistyczne, $\mathrm{tj}$. studium uwarunkowań i kierunków zagospodarowania przestrzennego, potwierdza, iż gminy w $100 \%$ wypełniają obowiązki prawne wobec ustawodawcy. Tylko jedna gmina uznała, iż dokumentację przygotowaną ma tylko częściowo, ale dopracowuje kompleksowe ujęcie studium dla obszaru całej gminy. 96\% ankietowanych gmin dysponuje miejscowymi planami zagospodarowania przestrzennego, chociaż w wielu przypadkach są to plany częściowe, sporządzane dla konkretnego obszaru lub regionu. Niestety w większości (93\% wskazań) jednostki gminne nie opracowały odrębnych planów zagospodarowania przestrzennego dla obszarów zagrożonych wystąpieniem powodzi, a tylko $9 \%$ uznało, iż przewiduje wykonanie takiego opracowania lub pracuje nad nim. Ujęcie w miejscowych planach zagospodarowania przestrzennego terenów zagrożonych powodziami nie jest rozwiązaniem kosztownym, a wysoce skutecznym, zwłaszcza na szybko rozwijających się terenach miejskich i podmiejskich. Takie działania mogą przyczynić się do minimalizacji ewentualnych strat ekonomicznych jakie mogłyby powstać w razie wystąpienia powodzi.

Kwestionariusz ankiety zawierał także pytania z zakresu zarządzania ryzykiem powodziowym w terenie. Przeprowadzona analiza wskazuje, iż 30\% badanych gmin przeznacza pod zabudowę tereny leżące na obszarach zagrożenia powodziowego, wprowadzając odpowiednie zapisy w miejscowych planach zagospodarowania przestrzennego. Pozostała większość (70\% analizowanych samorządów) wykazuje dużą świadomość ryzyka wynikającą z zagospodarowania takich terenów i sukcesywnie wyłącza je z racjonalnego wykorzystania, zwłaszcza zabudowy, przeznaczając na inne cele, mniej ryzykowne. Zmniejszanie powierzchni naturalnych obszarów zalewowych spowodowane postępującym, często chaotycznym zagospodarowywaniem i zabudową dolin rzecznych uznaje się obecnie za jedną z najważniejszych przyczyn wzrastających strat ekonomicznych i społecznych w przypadku wylewów rzek.

Przeważająca większość (65\% wskazań) samorządów wykazała, że na terenie gminy oznaczono obszary zagrożenia powodziowego. Te same gminy wskazały jednocześnie, że podejmują działania mające na celu wprowadzanie zakazów urbanizacji terenów zagrożonych tym ryzykiem. Można określić pewne prawidłowości, 
wskazując, iż struktura odpowiedzi w grupie gmin miejskich oraz wiejskich przyjmuje te same wartości procentowe $\mathrm{w}$ odniesieniu do podejmowanych działań polegających na oznaczeniu obszarów oraz ograniczaniu ich użytkowania na cele m.in. urbanistyczne.

W przypadku rozszerzonych badań dotyczących obszarów zagrożenia powodziowego dostrzec można pewną zależność. Jednostki samorządu, które odpowiedziały twierdząco, iż na terenach gmin systematycznie występują powodzie lub podtopienia również wykazały, że podejmują pewne działania minimalizujące oddziaływanie tych ryzyk w terenie. Do przedmiotowych działań można zaliczyć m.in. wyznaczanie obszarów zagrożenia powodziowego $\mathrm{w}$ dokumentach planistycznych oraz eliminowanie, wykluczanie lokalizacji zabudowy i urbanizacji na tych obszarach. Wykazana zależność wynika zapewne $\mathrm{z}$ doświadczeń nabytych przez samorządy w okresach wcześniejszych.

\section{Zakończenie}

Systematycznie, obszar województwa śląskiego jest narażony na działanie wielu ryzyk o charakterze katastroficznym. Najczęściej badane gminy wskazywały na występowanie podtopień/powodzi, huraganów, nadmiernych opadów śniegu oraz oblodzeń. Gminy właściwie identyfikują ryzyka zagrażające mieszkańcom na swoich terenach i podejmują działania prewencyjne oraz kompensacyjne wobec skutków tychże ryzyk. Gminy śląskie są bardzo dobrze przygotowane w zakresie dokumentacji, planów zarządzania kryzysowego co zapewnia właściwe reagowanie na zdarzenia katastroficzne. Dokumenty pozwalają samorządom zrealizować konkretne cele służące przede wszystkim bezpieczeństwu lokalnemu.

\section{Literatura}

Dyrektywa 2007/60/WE Parlamentu Europejskiego i Rady z 23 października 2007 r. w sprawie oceny ryzyka powodziowego i zarządzania nim, Dz. Urz. UE L 288/27.

EPA, 1992, Risk Assessment, EPA/600/M-91/034, United States Environmental Protection Agency, Washington, DC.

Monkiewicz J., 2000, Podstawy ubezpieczeń, t. I: Mechanizmy i funkcje, Poltext, Warszawa.

Prawo ochrony środowiska, Dz.U. z 2008 r. Nr 25, poz. 150 z późn. zm.

Ustawa z 20 lipca 2017 r. Prawo wodne, Dz.U. 2017 poz. 1556.

Ustawa z 27 marca 2003 r. o planowaniu i zagospodarowaniu przestrzennym, Dz.U. 2003 Nr 80, poz. 717 z późn. zm.

Zalewski A., 1994, Rola samorzadu terytorialnego w rozwoju gospodarki lokalnej, [w:] Samorzad terytorialny i gospodarka lokalna, Monografie i Opracowania, nr 381, Szkoła Główna Handlowa, Warszawa. 